\title{
Agro-morphological Characterization of Eight (08) Cowpea Accessions [(Vigna unguiculata (L.) Walp.)] from Benin and Ghana Introduced in Center-Benin
}

\author{
Saliou Bello ${ }^{1}$,, Raphiou Maliki², Appolinaire Adandonon ${ }^{3}$, Adolphe Azonkpin ${ }^{4}$, \\ Thomas Aidjo Houndete ${ }^{5}$, Gustave Dagbenonbakin ${ }^{6}$ \\ ${ }^{1}$ Agricultural Research Centre of South-Benin, National Agricultural Research Institute of Benin (CRA-Sud/INRAB), Attogon, Republic of \\ Benin \\ ${ }^{2}$ Agricultural Research Centre of Center-Benin, National Agricultural Research Institute of Benin (CRA-Centre/INRAB), Allada, Republic of \\ Benin \\ ${ }^{3}$ School of Crop and Seed Production and Management (EGPVS), National University of Agriculture, Ketou, Republic of Benin \\ ${ }^{4}$ Ouinhi Communal Unit, Territorial Agency of Agricultural Development (ATDA) of Pole 5, Ouinhi, Republic of Benin \\ ${ }^{5}$ Coton and Fibers Agricultural Research Centre (CRA-CF), National Agricultural Research Institute of Benin (CRA-CF/INRAB), Cotonou, \\ Republic of Benin \\ ${ }^{6}$ Smallholders Agricultural Productivity Enhancement Program (SAPEP) Project, National Agricultural Research Institute of Benin \\ (SAPEP/INRAB), Abomey-Calavi, Republic of Benin
}

\section{Email address:}

bello_saliou@yahoo.fr (S. Bello), malikird@yahoo.fr (R. Maliki), adanappo@yahoo.fr (A. Adandonon), azonadelle@gmail.com (A. Azonkpin), houndetet@yahoo.fr (T. A. Houndete), dagust63@yahoo.fr/dagust@yahoo.fr (G. Dagbenonbakin) *Corresponding author

\section{To cite this article:}

Saliou Bello, Raphiou Maliki, Appolinaire Adandonon, Adolphe Azonkpin, Thomas Aidjo Houndete, Gustave Dagbenonbakin. Agromorphological Characterization of Eight (08) Cowpea Accessions [(Vigna unguiculata (L.) Walp.)] from Benin and Ghana Introduced in Center-Benin. American Journal of Plant Biology. Vol. 6, No. 1, 2021, pp. 1-10. doi: 10.11648/j.ajpb.20210601.11

Received: August 28, 2020; Accepted: October 5, 2020; Published: January 25, 2021

\begin{abstract}
The present study allowed to characterize at agro-morphological level, eight (08) traditional cowpea accessions from Benin and Ghana in order to identify the best performing ones. The test was installed in a Randomized Complete Block (RCB) design with four (04) repetitions in a station in Savè in Center-Benin. The parameters studied are the date of flowering and maturation, the numbers of stems and leaflets per plant, the height of plants, the port of the stem, the lengths of pods and petiole, the weights of pods, tops, seeds and of 100 seeds, the seed yield, the colors of flowers, pods and seeds, the shapes of leaflets and of seeds, the size and the appearance of seeds. Xlsat version 2018.6 software was used for multi-component analysis to categorize accessions by their significant variables. SAS 9.2 software was used for the analysis of variance and the comparison of the means of variables. The number of branches, the length of the petiole, the height of the plants, the number of leaves, the length of the pods, the weights of the pods and of the tops had a positive influence on the cowpea seeds yield. The accessions were classified into three groups. The first group is made up of three (03) high-performance accessions, Nketewade, Mung bean lens and Songotra, with a short cycle of 61 to 62 days and a high yield of between $1050 \mathrm{~kg} / \mathrm{ha}$ and $1300 \mathrm{~kg} / \mathrm{ha}$. The second group is that of the Djetoko and black eye bean accessions of long-cycle from 80 to 88 days, with a yield of between $620 \mathrm{~kg} / \mathrm{ha}$ and $800 \mathrm{~kg} / \mathrm{ha}$. The third group is made up of false Cassoulet, Ennepa and Nsroma accessions with a short cycle of 62 to 65 days and a low yield of between $175 \mathrm{~kg} / \mathrm{ha} \mathrm{and} 230 \mathrm{~kg} / \mathrm{ha}$. Multilocal tests and genetic molecular characterization must be considered for a good valuation of these cowpea accessions.
\end{abstract}

Keywords: Plant Height, Performance, Pod Length, Number of Leaflets, Yield 


\section{Introduction}

The development base of most sub-Saharan African countries has long relied on agricultural production, which remains the main source of income for people. Although agriculture is not the only sector of activity, it remains an important sector for developing countries. In many tropical regions, crop systems result in insufficient productivity levels, making it difficult to meet food security goals [1].

Cowpea (Vigna unguiculata (L.) Walp.) is a legume grown and consumed in Benin as well as in the world. Most cowpea embalming is made in West Africa, covering $80 \%$ of the cultivated area with Central Africa [2]. Cowpea is grown for food subsistence and marketing and is a food whose consumption serves as an energy support for the installation and agricultural operations of maintenance and harvesting of crops such as cotton. In Ghana, cowpea is a major source of plant protein in the diet. It is eaten in the form of "tubaani", a form of steamed pudding of cowpea and "waakye", the equivalent of Benin's "atassi" or Togolese "ayimolou", a kind of mixture of rice and cowpea cooked together. It serves as a feeding for ruminants and fits well into crop assailing and rotation plans $[3,4]$.

In Ghana, a neighbouring country to Benin, the crop suffers yield losses of up to $100 \%$, due to drought-induced stress, viruses and Striga gesnerioides, also known as "witch grass". To address this situation, research has developed new varieties that mature in eight $(08)$ weeks, with a yield potential of nearly $4 \mathrm{t} / \mathrm{ha}$ compared to current yields with a potential of $4 \mathrm{t} / \mathrm{ha}$, and are highly tolerant to Striga gesnerioides, drought, rust and several viruses that attack cowpea, including the severe marrow and cucumber mosaic virus [5].

In Benin, the southern half of the country, characterized by annual rainfall of between 900 and $1350 \mathrm{~mm}$ over two seasons and well-drained tropical ferralitic and ferruginous soils, offers good conditions for growth and development for non-photoperiodic cowpea accessions [6].

Despite favourable agro-climatic conditions for the production of cowpea, including ecological plasticity and the multiple interests of its production, yields are generally low, ranging from $500 \mathrm{~kg} /$ ha to $650 \mathrm{~kg} / \mathrm{ha}$ in traditional cropping systems [3, 4, 7-10]. As a result, its crop is compromised by heavy pest infestations that greatly reduce yields to very low levels, from $200 \mathrm{~kg} / \mathrm{ha}$ to $400 \mathrm{~kg} / \mathrm{ha}$ [3-4, 10-15].

However, under favourable conditions, the yield potential can be as high as 1200 to $1500 \mathrm{~kg} / \mathrm{ha}$ [16]. It can reach $710 \mathrm{~kg} / \mathrm{ha}$ to $1065 \mathrm{~kg} / \mathrm{ha}$ if technical itineraries are well followed [17].

In this context, the deficit food balance was in the range of 6,700 to $12,500 \mathrm{t}$ /year for the period of 1995 to 2000 to be filled in sub-Saharan African countries including Benin, Togo, Ghana, Côte d'Ivoire and Niger [18].

The development and release of varieties with the application of better farming practices has substantially increased the production of cowpea in peasant environments in order to guarantee food security and contribute to poverty reduction.
In Niger and Benin, improved varieties of cowpea IT 89 KD-74-57, IT 90 K-372-1-2, IT 97 K-499-35, IT 97 K-49938, IT 98 K-205-8, T 99K-573-1-1, T 96D-610, KVX-30309-6G, TN-5-78 at erected, semi-erected and semi-rampant ports and variable cycles from 55 to 75 days with varying seeds yield levels of 1 to $1.7 \mathrm{t} / \mathrm{ha}$ are used for precocity, good production and pest resistance [19]. For various varieties grown in West Africa, the values of these parameters in the same orders of magnitude [20-22].

Indeed, many studies highlighted the existence of highperforming accessions in Benin that could meet the new conditions related to climate change [23].

This varietal diversity of cowpea has been estimated in Benin at about 124 traditional accessions including Kpodjiguèguè, Sakoaga, Narchagué and Atchawé which have been characterized agro-morphologically [3, 8-10, 24].

Most of the studies have focused on the varietal diversity of this culture, without documenting the production performance of traditional accessions [3-4, 9, 25-26].

The damage caused by these biotic and abiotic factors can be reduced, or even avoided, if the morphological and agronomic parameters of growth and development of the plant are well known to allow an improvement in yields.

Research work is therefore necessary for an extension of the range, a participatory selection and an optimal valuation of the varieties, accessions and cultivars available in different agro-ecological production zones. However, the low yield and the ignorance of the varied range of cowpea morphotypes linked to the dynamics of hybridization and agro-biodiversity and to varietal improvement have remained aspects not or little investigated.

By addressing these constraints, agro-morphological, cytogenetic, enzymatic and molecular genetic characterization techniques can be used to assess the agromorphological characteristics and performance of cowpea varieties and or accessions.

The purpose of this study is to assess the agromorphological diversity and the yield of eight (08) cowpea accessions from different agro-ecological areas of Benin and Ghana in order to select successful cowpea accessions adapted to the agro-climatic conditions of Central Benin.

\section{Material and Method}

\subsection{Study Area}

The test was installed from July to November 2018 on the experimental site of the Agricultural Research Center of the Center region of Benin of the National Agricultural Research Institute of Benin (CRA-Centre/INRAB) based in Ouoghi in the commune of Savè (Figure 1).

The choice of the study area is justified by the fact that it belongs to the largest production area and enjoys a favourable agro-climatic conditions for the production of cowpea cultivation in Benin [23]. 

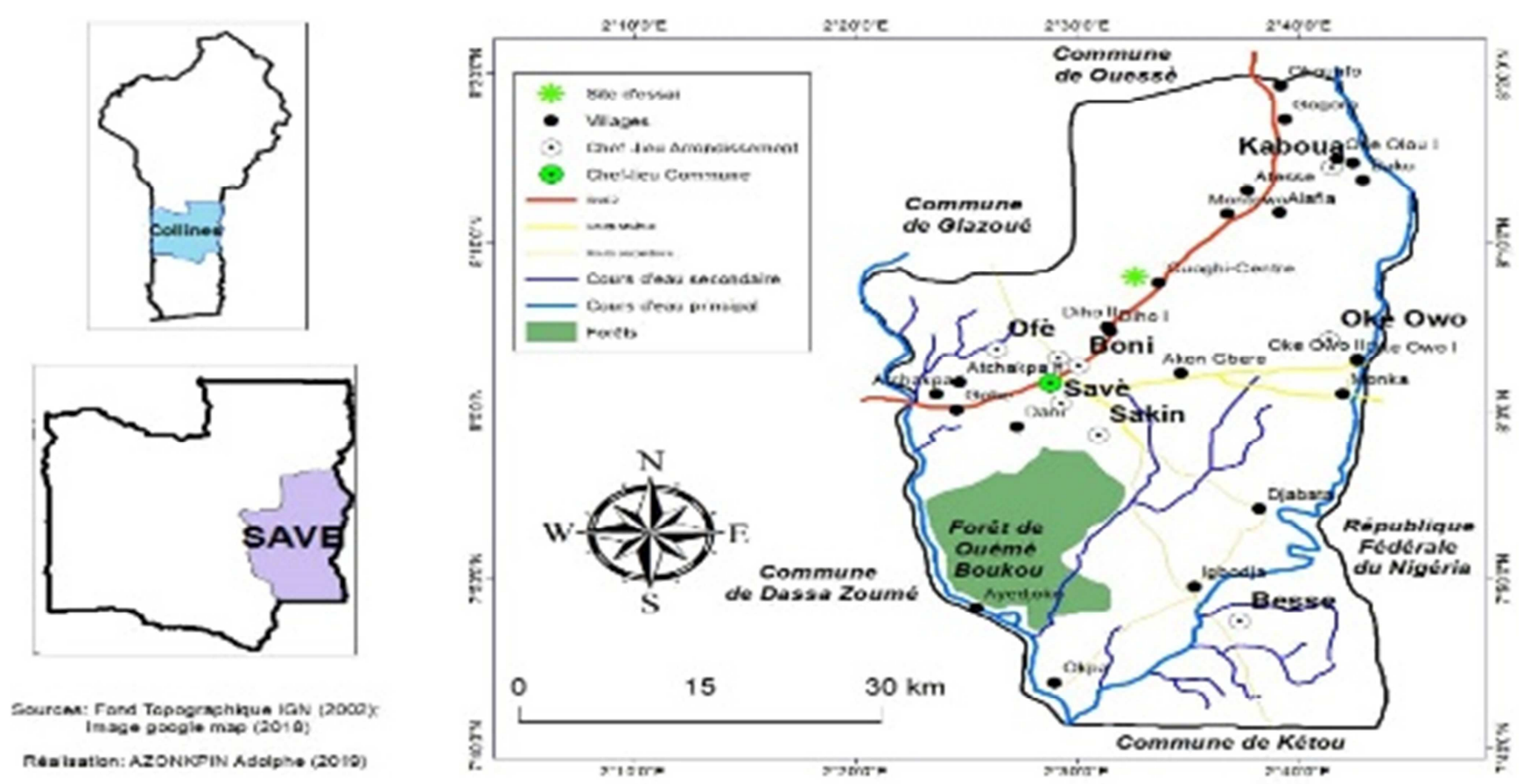

Figure 1. Map of Save locality showing the experimental site located at Ouoghi in Center-Benin.

\subsection{Plant Material}

The plant material consists of eight (08) cowpea accessions (Vigna unguiculata (L.) Walpers) called Mung bean lens, Djetoko, Black eye bean and False Cassoulet (Figures 2, 3, 4 and 5) acquired from women traders at the Bohicon market in South Benin and Nsroma, Ennepa, Nketewade and Songotra from different agro-ecological areas of Ghana (Figures 6, 7, 8 and 9).

The denominations of the accessions of Ghana and Benin are those assigned to them by their respective holders.

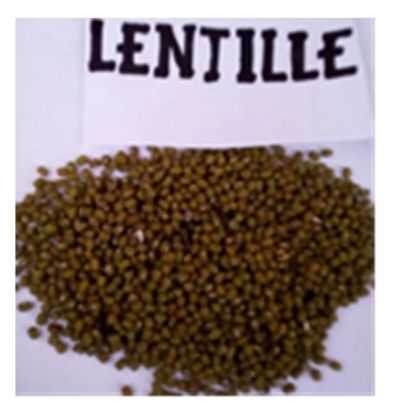

Figure 2. Seeds of Mung bean lens accession.

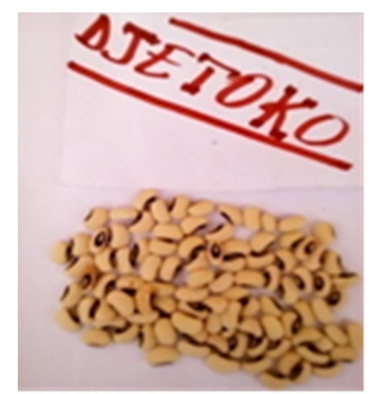

Figure 3. Seeds of Djetoko accession.

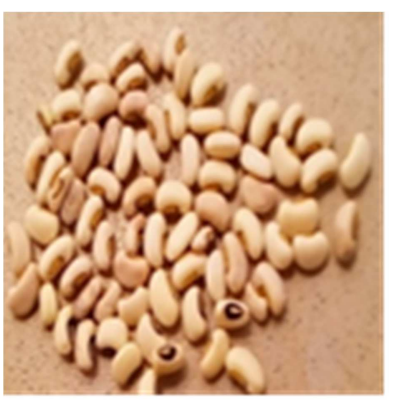

Figure 4. Seeds of black eye bean.

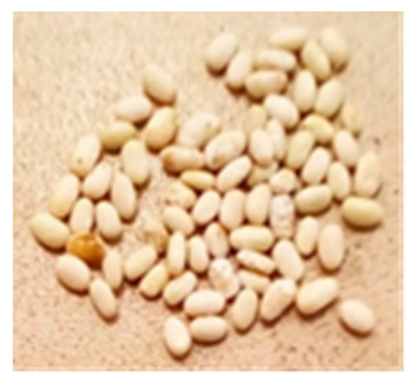

Figure 5. Seeds of False Cassoulet accession
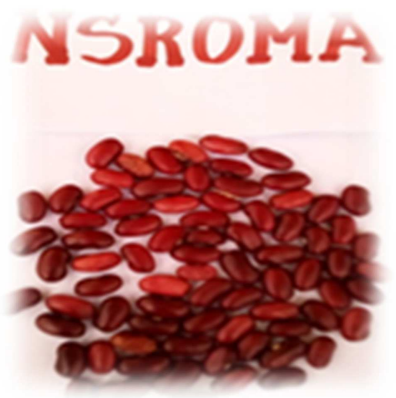

Figure 6. Seeds of Nsroma accession. 


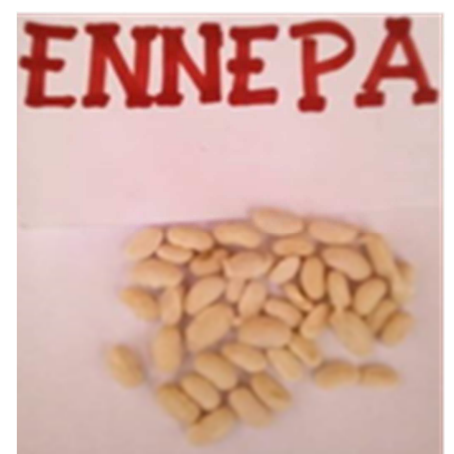

Figure 7. Seeds of Ennepa accession.

\section{NRETEWWAOL}

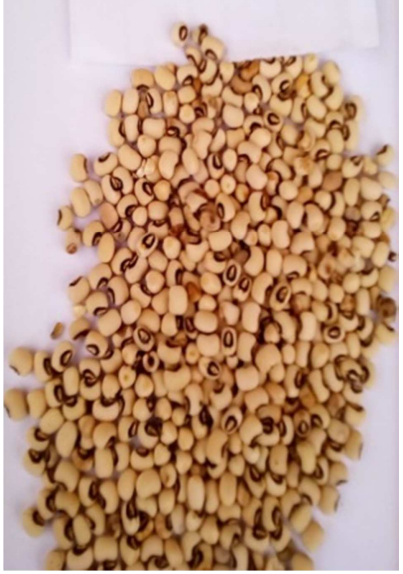

Figure 8. Seeds of Nketewade accession

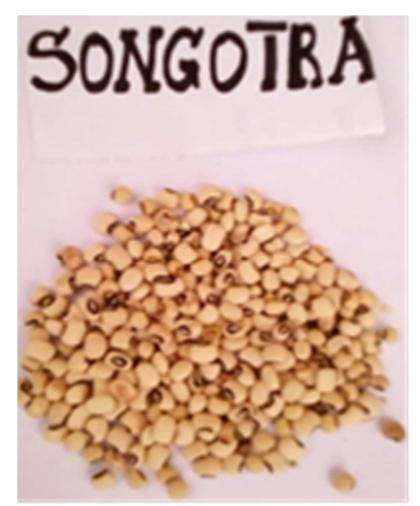

Figure 9. Seeds of Songotra accession.

\subsection{Method}

\subsubsection{Experimental Design}

The experimental device is a Randomized Complete Block (RCB) design with four (04) repetitions of eight (08) experimental units of which, each representing an accession of cowpea. The basic plots are separated by a $2 \mathrm{~m}$ wide driveway.

After the plowing of a plot having for previous crop, a fallow, the delimitation and the staking of the experimental plots, the sowing was carried out on July 27, 2018 on ridges, by hand in pockets with 1 to 2 seeds and at spacings of $80 \mathrm{~cm}$ between the lines and $40 \mathrm{~cm}$ between the pockets in accordance with the density recommended in Niger by some authors [27].

Two weedings made it possible to manage the grass. Three (03) phytosanitary treatments were carried out with a binary synthetic product called Lionguard composed of Cypermethrin and Dimethoate at the respective levels of 250 $\mathrm{g} / \mathrm{l}$ and $30 \mathrm{~g} / \mathrm{l}$ at a dose of one (01) 1/ha. The phytosanitary treatment started on the $31^{\text {st }}$ Day After Emergence (DAE) of cowpea and was continued at a periodicity of 14 days, but reduced to 10 days in the event of heavy infestation of the plants by pests.

The experimental unit is represented by an elementary plot of $4 \mathrm{~m}^{2}$ comprising 15 to 25 plants, of which 13 were observed. Each elementary plot has been labeled by the name of the accession and the date of sowing.

The total area of the test is $1600 \mathrm{~m}^{2}$, or $400 \mathrm{~m}^{2}$ per block repetition

\subsubsection{Data Collection}

For data collection, the morphological descriptors recommended by IBPGR [28] and those adopted by other authors [29] were used (Table 1).

In total, 20 variables including eight (08) qualitative and 12 quantitative were measured on each of the 13 plants observed.

For good representativeness of the samples, the 13 labeled plants were chosen and observed by accession along the two diagonals of the observation square. On each labeled plant, all the variables (Table 1) were observed, then coded afterwards for data entry. Pest damage and symptoms of disease caused by pathogens were described to document plant performance relatively to these two groups of pests.

\subsubsection{Data Analysis}

The data recorded on the collection sheets were entered in a database developed in the Excel spreadsheet software. The entered Excel spreadsheets were printed for verification and correction.

The data concerning the characteristics of the accessions were subjected to a Multiple Component Analysis (MCA) in the Xlsat software version 2018.6. The MCA made it possible to match each accession with the qualitative variables that best characterize it. To do this, the number of interpretation components was chosen on the basis of their inertia values. Indeed, the number of components for which the cumulative inertia values are greater than $50 \%$ is supposed to guarantee a better interpretation of the data. The contributions were used to match each variable or accession to the component on which it is interpreted.

For a qualitative variable to be retained as having a good contribution in the formation of a component and to be interpreted on this later, its contribution $\mathrm{k}$ for this component must be greater than $1 /$ number of qualitative variables $(1 / 8=0.125$ or $12.5 \%)$.

For an accession to be considered as having a good contribution in the formation of a component and to be interpreted on the latter, its contribution $\mathrm{k}$ for this component 
must be greater than $1 /$ number of accessions $(1 / 8=0.125$ or

contribution (positive or negative). $12.5 \%$ ). The data were used to determine the nature of this

Table 1. Quantitative and qualitative variables measured (from [28]).

\begin{tabular}{llll}
\hline $\mathbf{N}^{\circ}$ & Variables & Codes & Data description and collection \\
\hline & Quantitative variables & & \\
1 & Date of flowering & $\mathrm{Tfl}$ & Date of 50\% flowering in the plot of observation by the general aspect of the plot \\
2 & Date of maturing & $\mathrm{Tma}$ & Date of the first harvesting \\
3 & Number of stems & $\mathrm{NRa}$ & Counting of the number of stems at 45 and 60 Date After Sowing (DAS) \\
4 & Number of leaflets & $\mathrm{NFe}$ & Counting of the number of leaflets per plant at 45 DAS \\
5 & Height of plants & $\mathrm{Ht}$ & Measurement of the height of plants at 45 DAS \\
6 & Length of pods & $\mathrm{LGs}$ & Measurement of the wealthy and dried pods length per plant \\
7 & Length of petiole & $\mathrm{LPe}$ & Measurement of the length of petiole per plant and per accession at 45 DAS \\
8 & Weight of seeds & $\mathrm{Pgs}$ & Weighting of seeds per plant and per accession in observation plots at 13\% of water content \\
9 & Weight of 100 seeds & $\mathrm{P} 100 \mathrm{G}$ & Counting and weighting of 100 dried seeds of each accession in the four replicates \\
10 & Weight of full pods with seeds & $\mathrm{PGr}$ & Weighting of dried pods, per plant for each accession in each observation plot \\
11 & Yield of seeds per ha & $\mathrm{Rend}(\mathrm{kg} / \mathrm{ha})$ & Calculation of the weight of seeds measured in observation plots for an hectare \\
12 & Weight of tops per observation area & $\mathrm{pfn}$ & Weighting of tops in observation plots \\
$\mathrm{Qualitative} \mathrm{variables}$ & & \\
13 & Port of stem & $\mathrm{PrT}$ & 1. Creeping, 2. Semi-erected, 3. Erected \\
14 & Color of the flower & $\mathrm{CoF}$ & 1. White, 2. Brown 3. Yellow \\
15 & Shape of leaflets & $\mathrm{Ffo}$ & 1. Globular, 2. Lanceolated, 3. Subglobular \\
16 & Color of pods & $\mathrm{CGs}$ & 1. Cream, 2. Purple, 3. Black, 4. Yellow \\
17 & Color of seeds & $\mathrm{CGr}$ & 1. White 2. Pink, 3. Red, 4. Green, 5. Pinkish-yellow, 6. Purple, 7. Gray, 8. Cream-pink, 9) \\
18 & Size of seeds & $\mathrm{TGr}$ & Black \\
19 & Appearance of seeds & $\mathrm{AGr}$ & 1. Small, 2. Medium, 3. Big \\
20 & Shape of seeds & FGr Rough, 2. Smooth & 1. Rounded, 2. Slightly elongated, 3. Elongated \\
\hline
\end{tabular}

The quantitative data were subjected to a one-way (accession) analysis of variance at the significance level of $5 \%$, using SAS 9.2 software for the comparisons of means of quantitative variables for the accessions studied, namely: numbers of branches and leaflets, plant height, pod and petiole lengths, total seeds and 100 seeds weights, seeds and haulm pod weights, and seeds yield/ha.

In addition, a hierarchical classification of accessions by performance group was made with Xlsat version 2018.6 software on the basis of quantitative variables, namely: the height of the plants, the length of the pods, the number of leaflets per plant, the number of branching per plant, petiole length and seeds yield.

\section{Results}

\subsection{Number and Height of Leaves at $45 \mathrm{DAS}$}

Table 2 illustrated the average heights and numbers of leaflets per plant at 45 Days After Sowing (DAS). Analysis of the data in Table 2 indicated that the numbers of leaflets per plant and the heights of plants vary significantly $(\mathrm{P}=5 \%)$ depending on the accession. Black eye bean and Nketewade accessions had the highest number of leaflets, 188 leaflets per plant and 287 leaflets per plant respectively. The number of leaflets increased significantly to $94 \%$ on the Black eye bean accession compared to False Cassoulet, Nsroma and Ennepa accessions which had the lowest number of leaflets. With respect to plant height, Black eye bean, Ennepa and False Cassoulet accessions were not significantly different and exhibited the lowest height growth. The average plant height of the Nketewade accession is significantly higher than that of the other accessions, with a growth rate of over $60 \%$ compared to the Black eye bean accession which had the shorter size.

Thus, on the basis of the average height (Table 3), the accessions can be classified in order of decreasing importance as follows: Nketewade, Mung bean lens, Songotra, Djetoko, Nsroma, False Cassoulet, Ennepa and Black eye bean.

For the same variable, accessions whose groups do not bear the same letters are significantly different at the $5 \%$ threshold.

Table 2. Comparison of cowpea accessions based on the height and the number of leaflets at $45 \mathrm{DAS}$.

\begin{tabular}{lll}
\hline Accessions & $\begin{array}{l}\text { Height }(\mathbf{c m}) \text { à } 45 \\
\text { DAS } \pm \text { SEM }\end{array}$ & $\begin{array}{l}\text { Number of leaflets at } \\
\text { 45 DAS } \pm \text { SEM }\end{array}$ \\
\hline Nketewade & $53.27 \pm 1.02 \mathrm{a}$ & $287.60 \pm 13.07 \mathrm{a}$ \\
Mung bean lens & $46.37 \pm 1.17 \mathrm{~b}$ & $133.90 \pm 17.24 \mathrm{~b}$ \\
Songotra & $42.79 \pm 1.34 \mathrm{c}$ & $68.38 \pm 1.91 \mathrm{c}$ \\
Djetoko & $33.67 \pm 0.80 \mathrm{~d}$ & $54.90 \pm 3.17 \mathrm{~cd}$ \\
Nsroma & $27.48 \pm 0.46 \mathrm{e}$ & $39.00 \pm 1.52 \mathrm{~d}$ \\
False Cassoulet & $22.44 \pm 0.97 \mathrm{f}$ & $33.88 \pm 3.53 \mathrm{de}$ \\
Ennepa & $22.10 \pm 0.58 \mathrm{f}$ & $23.69 \pm 1.10 \mathrm{e}$ \\
Black eye bean & $20.77 \pm 0.81 \mathrm{f}$ & $188.90 \pm 2.00 \mathrm{e}$ \\
$\mathrm{F}$ & 179.45 & 131.15 \\
Pr $>\mathrm{F}$ & $<0.0001$ & $<0.0001$ \\
\hline
\end{tabular}

Source: Data of terrain, 2018

Legend: SEM: Standard Error of Means

F: Fisher' value Pr: Probability

DAS: Day after Sowing

\subsection{Comparison of Accessions Based on Yield Parameters}

The analysis of variance carried out on the production parameters indicated that the weight of filled pods, the weight of 100 seeds, the weight of the tops as well as the seed yield vary significantly depending on the accessions. The Mung bean lens accession followed by Nketewade 
accession presented the best performances for all production parameters, respectively of $450.25 \mathrm{~g}$ and $404.13 \mathrm{~g}$ for the weight of pods filled with seeds per square; of $16.20 \mathrm{~g}$ and $15.80 \mathrm{~g}$ for the weight of 100 seeds; of $185.50 \mathrm{~g}$ and $162.63 \mathrm{~g}$ for the weight of the tops per square; and of $1323.75 \mathrm{~kg} / \mathrm{ha}$ and $1207.50 \mathrm{~kg} / \mathrm{ha}$ for the seeds yield.
The lowest yield parameters were observed for False Cassoulet and Nsroma accessions. Accessions can be classified in decreasing order of yield as follows: Mung bean lens, Nketewade, Songotra, Black eye bean, Djetoko, Ennepa, Nsroma and False Cassoulet (Table 3).

Table 3. Comparison of cowpea accessions based on means of yield.

\begin{tabular}{|c|c|c|c|c|}
\hline Accessions & Weight of pods (g) \pm ES & Weight of 100 grains (g) \pm ES & Tops weight (g) \pm SEM & Seeds yield $(\mathrm{kg} / \mathrm{ha}) \pm \mathrm{SEM}$ \\
\hline Mung bean lens & $450.25 \pm 9.15 \mathrm{a}$ & $16.20 \pm 0.00 \mathrm{a}$ & $185.50 \pm 3.75 a$ & $1323.75 \pm 27.03 a$ \\
\hline Nketewade & $404.13 \pm 10.66 b$ & $15.80 \pm 0.00 \mathrm{a}$ & $162.63 \pm 4.17 b$ & $1207.50 \pm 32.50 \mathrm{~b}$ \\
\hline Songotra & $350.38 \pm 9.31 \mathrm{c}$ & $9.20 \pm 0.00 b$ & $142.13 \pm 3.80 \mathrm{c}$ & $1041.25 \pm 27.57 \mathrm{c}$ \\
\hline Black eye bean & $285.13 \pm 4.71 \mathrm{~d}$ & $9.05 \pm 0.32 b$ & $122.63 \pm 1.77 \mathrm{~d}$ & $812.50 \pm 14.93 \mathrm{~d}$ \\
\hline Djetoko & $230.63 \pm 9.33 \mathrm{e}$ & $9.05 \pm 0.32 b$ & $102.63 \pm 4.17 \mathrm{e}$ & $640.00 \pm 25.82 \mathrm{e}$ \\
\hline Ennepa & $75.00 \pm 7.65 f$ & $8.30 \pm 0.00 \mathrm{c}$ & $25.00 \pm 2.55 f$ & $250.00 \pm 25.50 \mathrm{f}$ \\
\hline Nsroma & $61.50 \pm 4.66 f$ & $6.10 \pm 0.00 \mathrm{~d}$ & $20.50 \pm 1.55 f$ & $205.00 \pm 15.55 \mathrm{f}$ \\
\hline $\mathrm{F}$ & 419.12 & 644.25 & 476.49 & 381.21 \\
\hline $\operatorname{Pr}>F$ & $<0.0001$ & $<0.0001$ & $<0.0001$ & $<0.0001$ \\
\hline
\end{tabular}

Source: Data of terrain, 2018

Legend: SEM: Standard Error of Means; F: Fisher'Value; Pr: Probability

For the same variable, accessions whose groups do not bear the same letters are significantly different at the $5 \%$ threshold.

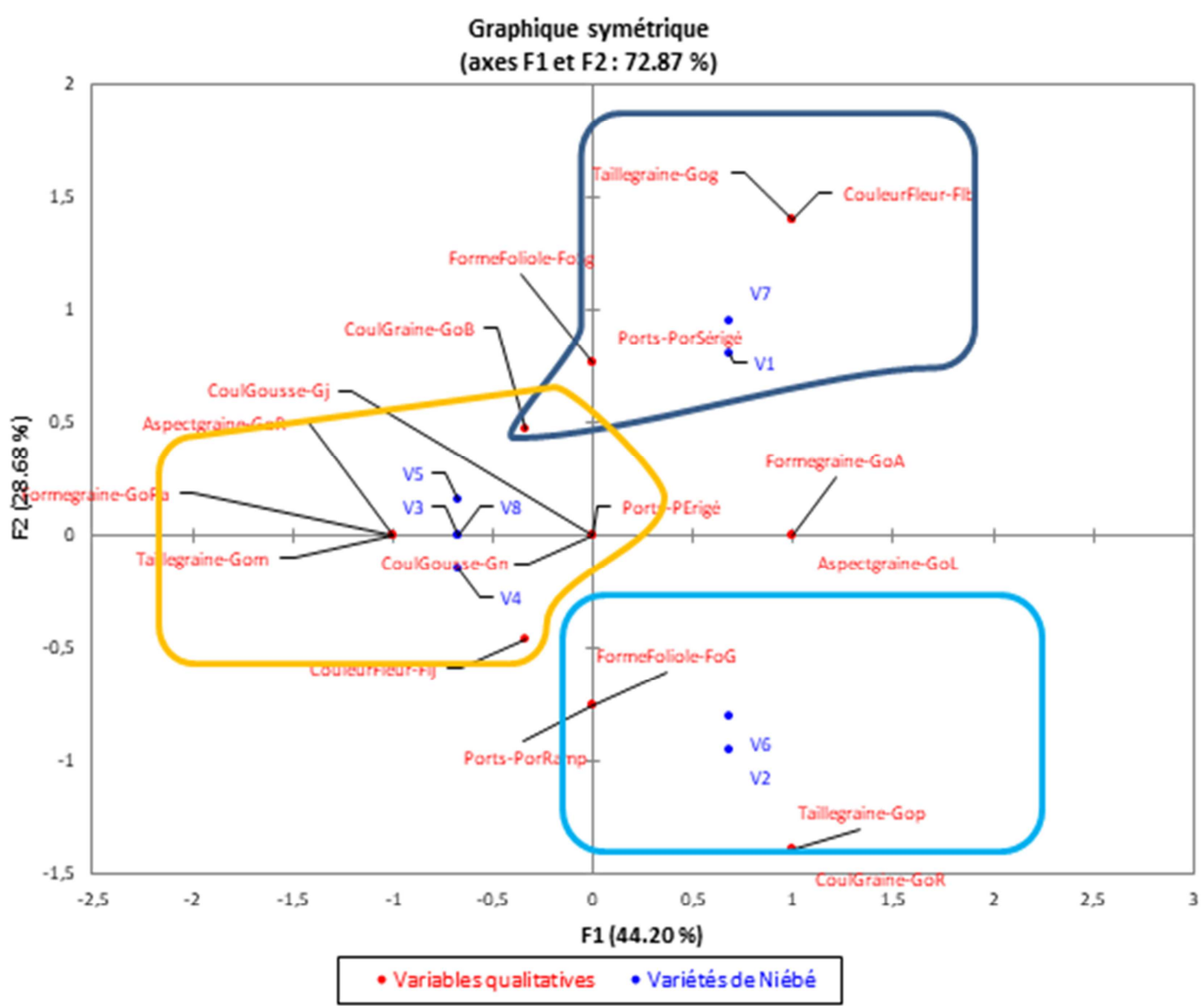

Legend: V1: Mung bean lens, V2: Djetoko, V3: Black eye bean, V4: False Cassoulet, V5: Nsroma, V6: Ennepa, V7: Nketewade, V8: Songotra.

Figure 10. Symmetric projection of qualitative variables and accessions

(i) Ports-Erected: erected port; (ii) Ports-PorRamp: creeping port; (iii) Ports-PorSérigé: semi-erect habit; (iv) Color Flower-Flb: flowers of white color; (v) Color FlowerFlj: flowers of yellow color; (vi) Foliole-FoG form: globular leaflet; (vii) Foliole-FoSg form: globular leaflet; (viii) CoulGousse-Gj: pod of yellow color; (ix) CoulGousse-Gn: pod of black color; (x) CoulGraine-GoB: seed of white color; (xi) CoulGraine-GoR: seed of red color; (xii) Seed-Gog size: 
large seed; (xiii) Seed-Gom size: seed of medium size; (xiv) Seed-Gop size: small size seed; (xv) Seed-GoL aspect: seed of smooth appearance; (xvi) Seed-GoR appearance: seed of rough appearance; (xvii) Seed-GoA form: rounded seed; (xviii) Seed-GoPa form: flat-shaped seed.

\subsection{Symetrical Projection of Variables}

Figure 10 illustrates the link between accessions and their characteristics. Analysis of the figure 10 showed that the accessions exhibit distinctive morphological characteristics by group. Mung bean lens and Nketewade accessions are semi-erect, while Nketewade has large seeds. The Mung bean lens has small seeds and an erect habit.

Mung bean lens and Ennepa accessions are distinguished from other accessions by their small seeds. The Mung bean lens accession has subglobular shaped leaflets and the False Cassoulet accession has lanceolate petioles. Nsroma has red colored seeds and all other accessions have white colored seeds.

Black eye bean, False Cassoulet, Nsroma and Songotra accessions are characterized by medium-sized seeds. The Songotra accession has yellow flowers, while for the other three, the flowers are white. The pods are black for the Mung bean lens and yellowish for the other three accessions. The seeds are rough for the Songotra accession and smooth for the other three accessions.

In addition, certain characteristics such as the seeds of rounded shape and the smooth appearance are common to Mung bean lens, False Cassoulet, Nsroma and Ennepa accessions. The white color of the seeds is common to Djetoko, Black eye bean, False Cassoulet, Ennepa, Nketewade and Songotra accessions.

\subsection{Categorization of Accessions by Groups of Performance}

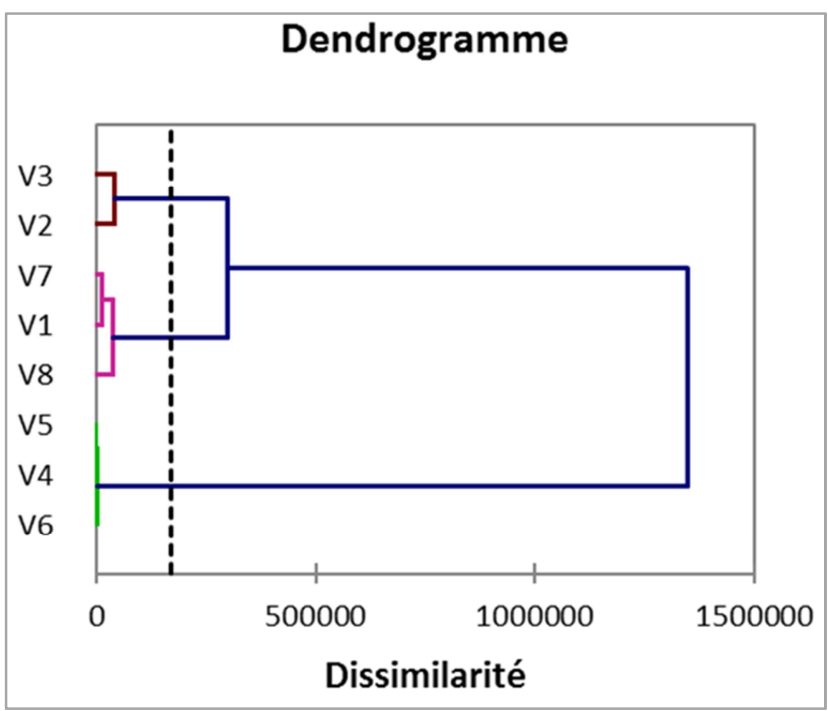

Figure 11. Dendrogram of classification of accessions of cowpea.

Source: Field data, 2018.

Legend: V1: Mung bean lens, V2: Djetoko, V3: Black eye bean, V4: False Cassoulet, V5: Nsroma, V6: Ennepa, V7: Nketewade, V8: Songotra.

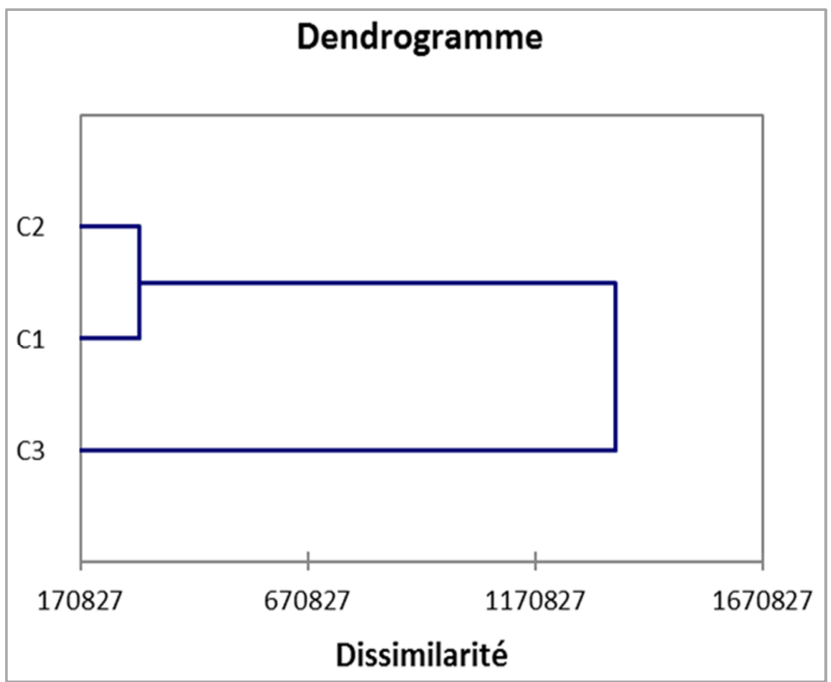

Figure 12. Dendrogram of classification of accessions of cowpea.

Source: Field data, 2018.

Legend: C1: Group 1; C2: Group 2; C3: Group 3.

The analysis of the results from the numerical classification made it possible to group the accessions into three (03) groups. Figures 11 and 12 illustrating the dendrograms of accessions classification indicated that Mung bean lens, Nketewade and Songotra accessions belong to group 1, Djetoko and Black eye bean accessions belong to group 2 and False Cassoulet, Nsroma and Ennepa accessions belong to the group 3 .

\section{Discussion}

Agro-morphological characterization is essential for improving the genetic diversity of cowpea [30]. The present study made it possible to determine the agro-morphological characterization of eight (08) cowpea accessions from Benin and Ghana on the one hand and to determine the performing accessions on the other hand. At the end of the harvest, the pods weight, the 100 seeds weight and the yield per square showed different levels of mean values depending on the accession.

The weights of 100 seeds of the eight (08) accessions obtained which varied between $5.40 \mathrm{~g}$ to $16.20 \mathrm{~g}$ corroborate the values obtained for the same parameter by other authors which are between 4.00 and $23.75 \mathrm{~g}$ [24]. For some varieties, these results are similar to those of some authors who reported values between $8.53 \mathrm{~g}$ and $9.51 \mathrm{~g}$ for varieties IT 97K499-35 and IT 98K205-8 respectively for fertilization with NPK and Urea and with NPK combined to urea and compost [31].

The seeds yields of the varieties obtained in the framework of the present study which varied from $201.25 \mathrm{~kg} / \mathrm{ha}$ to $1323.75 \mathrm{~kg} / \mathrm{ha}$ are lower to the levels determined by other authors, which ranged from $517 \mathrm{~kg} / \mathrm{ha}$ to $2696.50 \mathrm{~kg} / \mathrm{ha}$ [24]. Seeds yields of certain accessions such as Black eye bean and Djetoko evaluated in the framework of this study are similar 
to the values of $480 \mathrm{~kg} / \mathrm{ha}$ and $720 \mathrm{~kg} / \mathrm{ha}$ determined by other authors, respectively for the varieties IT 97K499-35 and IT 98K205-8 [31].

Statistical analysis of qualitative characteristics, namely: the shape of the stem, the color of the flowers, the shape of the leaflets, the color of the pods, the color of the seeds, the size of the seeds, the appearance of the seeds and the shape of the seeds allowed to highlight the presence of a diversity of characters between the accessions. This result is consistent with those reported by a similar study [32].

The average of 27 DAS to 64 DAS recorded for the date of flowering at $50 \%$ of the eight (08) traditional accessions studied corroborates the results relating to the cycle of 53 DAS determined for very early accessions among 94 accessions from Ghana and Mali [33]. Some accessions studied in the present study have a later cycle in relation to their maturity. These are the black eye bean and Djetoko accessions, both with creeping habit, with 88 DAS and 80 DAS respectively. On the other hand, the Songotra accession presented the shortest maturity period of 61 DAS, close to the other accessions with semi-erect habit.

The analysis of variance carried out on the production parameters showed that the weight of filled pods, the weight of 100 seeds, the weight of tops as well as the seeds yield varied significantly depending on the accession. These differences obtained between the accessions for the weight of 100 seeds on the one hand and the seed yield on the other hand have already been mentioned in a similar study related to cowpea accessions from Ghana and Mali [33]. The accumulation of reserves in seeds depends not only on the type of genotype, but also on climatic factors [34]. However, the average values obtained for these two parameters were low and would probably be explained by the level of initial soil fertility characterized by a weakness and poverty and the unfavorable environmental conditions. Finally, the low yield levels observed for most accessions could be explained in part by various attacks of pests suffered by the plants during the vegetative and the reproductive phases. The high coefficients of variation observed for a good number of characters indicated a strong heterogeneity within the accessions for the studied characters.

The management of the crop cycle of cowpea accessions has an important agronomic consideration, in that, it can help mitigating the negative effects of climate change. To achieve this goal, earlier accessions can be considered as very good candidates for a variety selection program.

\section{Conclusion}

The existence of significant agro-morphological variability between the eight (08) accessions was demonstrated on the basis of eight (08) qualitative and quantitative characters. Morphologically, seeds of the cowpea accessions studied are white and red, with yellowish and black pods that are more or less dehiscent, elongated and short, suggesting several possible uses.

To enhance this varietal diversity of cowpea characterized in three (03) performance groups, the earliest and highyielding accessions can be tested in comparison to local varieties grown in different agro-ecological zones to assess their behavior in variable environments.

From this point of view, the most efficient accessions namely: Mung bean Lens, Nketewade and Songotra can be developed in the farms of Center-Benin. However, the high agro-morphological variability highlighted within the studied accessions requires that, in addition to the test of production performance, their aptitude for storage and conservation as well as a molecular genetic analysis be carried out for the participatory selection of suitable cultivars and the assessment of their genetic pool quality.

Expanding the range of available cowpea accessions can support the ongoing efforts of producers to have and manage efficient cowpea accessions.

\section{Acknowledgements}

The authors thank the Coordination Unit of the Smallholder Agricultural Productivity Enhancement Program (SAPEP), particularly Dr BATIONO André, the Regional Coordinator, Dr Ir. DAGBENONBAKIN Gustave, the National Coordinator of Benin, and MSc. FLATIN Olivier, the Seeds Unit Manager of the project, for making available to the 1st author of this article, Dr Ir. BELLO Saliou, the strains of cowpea accessions introduced from Ghana, without which the present study could not have been carried out.

\section{References}

[1] A. S. Langyintuo, J Lowenberg-DeBoer, M. Faye, D. Lambert, G. Ibro, B. Moussa, A. Kergna, S. Kushwaha, S. Mussa, G. Ntoukam. "Cowpea supply and demand in West, and Central Africa". In Cowpea Production in Field Crops Research, Peter HG, Anthony EH, Dernot PC (eds)," 2003, pp. 59-68.

[2] F. M. Quin, "Introduction. In: advances in cowpea Research" Sing B. B., Mohan Raj, D. R., Dashiel K. E. and Jackai, L. E. $\mathrm{N}$ (eds), Co-publication of international Institute of tropical Agriculture (IITA), Ibadan, Nigeria and Japan International Research center Agricultural Science (JICARS), 1997, pp. 1128.

[3] Bello, S., Baco, M. N. (2015). Importance, typology of holders and local taxonomy of cowpea varietal diversity in Northeastern Benin, Annales des Sciences Agronomiques, 19 (2) special volume: 337-366, ISSN 1659-5009, 2015.

[4] S. Bello, A. Affokpon, CA Djihinto, and M. Idrissou-Touré, "Sensitivity to pests, seed production and agro-pastoral interests of the cowpea variety IT 95K-193-12 in South Benin," 2016, 12 p. Technical and Information Document (DT\&I), Legal deposit $\mathrm{N}^{\circ} 9054$ of 11/28/2016, 4th quarter, National Library of Benin, ISBN: 978-99919-2-616-2.

[5] J. Abalo, "Ghana: soon improved cowpea for smallholders," Ghana, Projects, Africa Top Success, http://africatopsuccess.com, 2018, posted 10/27/2018, accessed July 16, 2020. 
[6] CBDD (Beninese Center for Sustainable Development), "Revue bimestrielle," $\mathrm{N}^{\circ} 11$, July-August 2000, p 7.

[7] INRAB, "Master Plan for Agricultural Research (PDRA) of Benin.” INRAB, Cotonou, Benin, 1996, 12 p.

[8] S. Bello, "Testing of some methodological approaches to assess the diversity of plant genetic resources: application to cowpea (Vigna unguiculata (L.) Walp:) in the North-East of Benin," Thesis by DEA, FSA / UAC, 2005, 152 p.

[9] Baco, M. N., Ahanchédé, A., Bello, S., Dansi, A., Vodouhè, R., Biaou, G., Lescure, J. P. (2008). Assessment of management practices for cowpea varietal diversity (Vigna unguiculata): a methodological attempt experimented in the village of Sori in Benin. Published in "Cahiers agriculture, Caa070166) R1. http://www.cahiersagricultures.fr/. (IF in $2013=0.597)$.

[10] Bello, S., Baco, M. N., Djihinto, C. A., Ahanchede, A. (2018a). Management practices for cowpea varietal diversity in North-East Benin, Bulletin de la Recherche Agronomique du Bénin (BRAB), 84: 28-42. ISSN on paper (on hard copy): 1025-2355 and ISSN on line (on line): 1840-7099, http://www.slire.net and http://www.inrab.org.

[11] Bello, S., Babalakoun, A. O., Zoudjihékpon, J., Coulibaly, K. A. (2018b). Diversity of cowpea entomofauna (Vigna unguiculata (L.) Walpers) in northwestern Benin, Journal of Applied Biosciences, 132: 13424-13438, ISSN 1997-5902.

[12] Bello, S., Babalakoun, O. A., Coulibaly, K. A., Zoundjihekpon, J. (2019a). Efficacy of aqueous plant extracts for the control of thrips on different cultivars of cowpea (Vigna unguiculata) in North-West Benin. Ann. UP, Sci Series. Nat. Agron. June 2019; 9 (1): 107-122, ISSN: 18408494, eISSN: $1840-8508$.

[13] Bello, S., Babalakoun, O. A., Coulibaly, K. A., Zoundjihekpon, J. (2019b). Evaluation of the losses in stock of cowpea seeds treated in the field with aqueous extracts of plants in the North-West of Benin. International Journal of Innovation Sciences and Research, 8 (8): 1492-1502, ISSN: 2319-9369, website: http://www.ijisr.com.

[14] Bello, S., Babalakoun, O. A., Coulibaly, K. A., Zoundjihekpon, J. (2020a). Efficacy of aqueous plant extracts for control of bedbugs on cowpea (Vigna unguiculata (L.) Walpers) cultivars in northwestern Benin. Agricultural Science Research Journal, 10 (1): 15-30, ISSN-L: 2026-6073.

[15] Bello, S., Babalakoun, A. O., Zoundjihekpon, J., Coulibaly, A. A. (2020b). Efficacy of plants aqueous extracts for greenflies management on six cowpea cultivars in northwest of Benin. International Journal of Recent Advances in Multidisciplinary Research, 7 (5): 5810-5817. www.ijramr.com.

[16] N. Aho, "Constraints and advantages of cowpea. In: Pulses,"International Foundation for Science," FIS- Grev Turegatan, Stockholm, Sweden, 1988, p. 19.

[17] Aly, D., Ahouansou, R. H., Mama, V. J., Olou, D., Agli, C. (2017). Participatory evaluation and selection of improved cowpea varieties in rural areas in the Couffo department in Benin. African Crop Science Journal, 25 (4): 509-520. ISSN 1021-9730 / 2017. www.ajol.info/ and www.bioline.org.br/cs, DOI: http://dx.doi.org/10.4314/acsj.v25i4.8.

[18] BG Soule, "The cowpea market in the Gulf of Guinea countries (Ivory Coast, Ghana, Togo, Benin and Nigeria)," Regional Analysis and Social Expertise Laboratory (LARES),
Provisional version, January 2002, 31 p.

[19] I. Baoua, M. Nouri, AK Saidou, and L. Amadou, "Some new varieties of early cowpea productive and resistant to pests," Technical sheet $N^{\circ} 003-2013$ / INRAN, Republic of Niger, Ministry of Agriculture, National Institute of Agronomic Research of Niger (INRAN), Tropical Legumes II (eds), 2013, 3 p. Website: http://inran.refer.ne, Email: inran@intnet.ne or dginran@yahoo.com.

[20] I. Ali, "Agronomic performances of eight varieties of dual-use cowpea, their forage quality and their tolerance towards main enemies," University Abdou Moumouni of Niamey. Thesis for the Diploma of Agricultural Techniques Engineer, 2005, 48 p.

[21] Y. Dugje, LO Omoigui, F. Ekeleme, AY Kamara, H. Ajeigbe, "Cowpea production in West Africa," Farmer's guide, International Institute of Tropical Agriculture (IITA), Ibadan, Nigeria, May 2009, 27 p.

[22] RECA, "Cowpea varieties registered in the National Catalog of Plant Species and Varieties (CNEV) of Niger," 2012, 3 p.

[23] Gbaguidi, A. A., Dansi, A., Loko, L. Y., Dansi, M., Sanni, A. (2013). Diversity and agronomic performances of the cowpea (Vigna unguiculata L. Walp.) landraces in Southern Benin. International Research Journal of Agricultural Science and Soil Science, 3 (4): 121-133.

[24] Gbaguidi, A. A., Assogba, P., Dansi, M., Yedomonhan, H., Dansi, A. 2015. Agro-morphological characterization of cowpea accessions cultivated in Benin. International Journal of Biological and Chemical Science, 9 (2): 1050-1066.

[25] Zannou, A., Ahanchédé, A., Struik P. C., Richards, P., Zoundjihékpon, J., Tossou R., Goodhue S., 2004. Yam and cowpea diversity management by farmers in the guinea-sudan transition zone of Benin. N. J. A. S Wageningen Journal of Life Sciences, 52 (3-4): 393-420.

[26] Abadassi, J. (2014). Agronomic Traits of Cowpea (Vigna unguiculata (L.) Walp.) Populations cultivated in Benin. International Journal of Science and Advanced Technology, 4 (2): 4.

[27] A. Tchokanaka, E. O. Salissou, A. B. Cheik, L. I. Mama, and I. Bachir, "Technical economic sheet for the cultivation of cowpea," Zinder region, 2016, 3 p.

[28] IBPGR, "Descriptors for Cowpea," IBPGR, Rome, 1983, 34 p.

[29] Cobbinah, F. A., Addo-Quaye, A. A., Asante, I. K. (2011). Characterization, evaluation and selection of Cowpea (Vigna unguiculata (L.) Walp) accessions with desirable traits from eight regions of Ghana, ARPN Journal of Agricultural and Biological Science, 6 (7): 21-32.

[30] Radhouane, L. (2004). Study of morpho-phenological variability in Pennisetum glaucum (L.) R. Br. Plant Genetic Resources Newsletter, 138: 18-22.

[31] H. I. Oumarou, B. Soumana, A. Toulou, B. Yamba, "Evaluation of seed and haulm yields of improved and local varieties of cowpea [Vigna unguiculata (L.) walp.] In school fields and in seed multiplication fields in Karma (Niger)," 2017, 9 p.

[32] Stoilova, T., Pereira, G. (2013). Assessment of the genetic diversity in a germplasm Collection of cowpea (Vigna unguiculata (L.) Walp.) using morphological traits. African Journal of Agricultural Research, 8 (2): 208-215. 
[33] Doumbia, I. Z., Akromah, R., Asibuo, J. Y. (2013). Comparative study of cowpea germplasms diversity from Ghana and Mali using morphological characteristics. Journal. Plant Breed. Genetic, 01 (03): 139-147.
[34] Khan, A., Bari, A., Khan, S., Shan, N. H., Zada, I. (2010). Performance of cowpea genotypes at higher altitude of NWFP. Pak Journal Botanique, 42 (4): 2291-2296. 